ISSN: 2362-1303 (Paper) | eISSN: 2362-1311 (Online)

JOURNAL OF ADVANCED ACADEMIC RESEARCH (JAAR)

June 2020

\title{
Relation of Global Solar Radiation with Temperature, Rainfall, Sunshine Duration and Clearness Index at Western Himalayan Region, Nepal
} Bed Raj KC ${ }^{1}$ and Shekhar Gurung ${ }^{2}$

${ }^{1}$ Mahendra Multiple Campus, Tribhuvan University, Nepalgunj, Nepal

${ }^{2}$ Central Department of Physics, Tribhuvan University, Kathmandu, Nepal

\section{Corresponding Author}

Bed Raj KC

Email: bedrajkc@yahoo.com

\begin{abstract}
The global solar radiation is measured at the horizontal surface by calibrated pyranometer at $\operatorname{Jumla}\left(29.27^{\circ} \mathrm{N}\right.$ to $\left.82.18^{\circ} \mathrm{E}, 2514.0 \mathrm{~m}\right)$. The effect of different physical as well as meteorological parameters to the intensity of global solar radiation was analyzed. This paper compares global solar radiation with sunshine duration, temperature, and rainfall and clearness index. This paper also explains the monthly, seasonal variation of global solar radiation. The annual average global solar radiation is $18.36 \mathrm{MJ} / \mathrm{m}^{2}$ /day which is sufficient to promote solar active and passive solar energy technology at Himalaya terrain Jumla and other similar geographical locations. This novel result can be used for location of similar meteorological and geographical characteristics at which solar data are not available.
\end{abstract}

\section{KEYWORDS}

Atmospheric pollution, Clearness factor, Meteorological and Geographical factors, Solar radiation

\section{INTRODUCTION}

Energy is the lifeblood of developmental process. The development of a country depends upon amount of energy used by nation, in terms of food and fuel item. Energy is measured by the amount of work done by an object. Therefore, energy is said as an important factor like a development indicator, which provides vital inputs for survival and economic prosperity in social, national and global perspectives of human. Sun provided resource is essential in the purpose of transportation, telecommunication, industrial development, other infrastructural development and development of education of less financing country (KC, 2019).

Till the middle of the $19^{\text {th }}$ century, wood, hay straw, coal, mustard oil and vegetable secretion had sometimes constituted the main source of energy and smaller contribution from fossil fuels would take a place for burning hearths and ovens in almost all people's houses. By the end of early $20^{\text {th }}$ century many dominant energy sources became the sole products out of mineral gasoline, other widely accepted fuels like gases, hydropower and nuclear energy 
ISSN: 2362-1303 (Paper) | eISSN: 2362-1311 (Online)

JOURNAL OF ADVANCED ACADEMIC RESEARCH (JAAR)

June 2020

ultimately. The reserves of fossil fuel are very limited and are being depleted very fast and search of alternate energy sources are being very much important. Fossil fuels need to be gradually replaced by renewable sources of energy (WECS, 2010).

The electricity intake demand and the number of consumers would simultaneously have increased at a rate of approximately $9 \%$ per year but generation of additional power plant is almost in a stable situation (Nepal Energy Situation, 2013). In Nepal, there is less demand and supply trend for renewable energy and within this very few percentages of utility of power solar energy is used. To minimize the problem arisen due to lack of resource availability, Nepal is trying to cope with the sole renewable energy generation procedure (KC and Gurung, 2015).

Among the various types of unpolluted and utilizable power mechanism, the sun produced radiation appears as being the most favored option because of its infinite and nonpolluting nature to whole environment. This energy is an ideal alternative source type of environmental measures in usage because it is abundant and inexhaustible (Okonkwo, 2014). The average global solar radiation in the place of Nepal shows a difference in intensity level ranging as 3.6-6.2 $\mathrm{kWh} / \mathrm{m}^{2}$ day $^{-1}$, such small burning star emits rays for up to 300 days in each year, because of topographical irregularity, usage of fossil fuel thereby deteriorates an environment and meteorological changes effect on penetrating power of sunlight entered into atmospheric site before horizontal ground. Thus, Nepal lies in a favorable insulation zone in the world (Adhikari et al., 2013). In another way solar light emission has appeared a very suitable form of energy for the country like Nepal. It is renewable, inexhaustible, pollution free and environment friendly type of resource among many renewable energy options in the world (Nisha, 2016). The emission of sun rays when absorbed for electric transmission would help to minimize the power supply demand of the country. Solar energy is valuable form of renewable energy, telecommunications, airports etc. It has the potential to produce electricity by the use of photovoltaic cells and can be used for providing power to motors, refrigerators, lights, communication equipment, and so on (Tsering, 1991). Solar energy is at present becoming more and more popular as the oil prices are getting so kept as for increasing (Energy Efficiency and Conservation Agency, 2001).

\section{Study Area}

The study site Jumla representsHimalayan region of Nepal. It is a remarkable place of natural beauty. There are very low temperatures from November to January it can reach $-11^{0} \mathrm{C}$. It is hottest from May to July. During this time temperature varies between $30^{\circ} \mathrm{C}$ and $12^{\circ} \mathrm{C}$. The air in Jumla is very dry and Pre- and post-monsoon winds also impact livelihoods. There is less rainfall in comparison to other districts. The main tourist season of this area is August to November. It is located at elevation $915 \mathrm{~m}$ to $4,679 \mathrm{~m}$ above sea level. Jumla's topography is characterized by three parts: high hill and rocky mountain, partially covered by snow; lower hill, with grazing 
ISSN: 2362-1303 (Paper) | eISSN: 2362-1311 (Online)

JOURNAL OF ADVANCED ACADEMIC RESEARCH (JAAR)

June 2020

meadows; and low lands, where most agriculture and towns are found. Jumla is rich in natural resources. Medicinal herbs can be harnessed for income generation (UNFCO, 2012).

\section{Instrument and Methods}

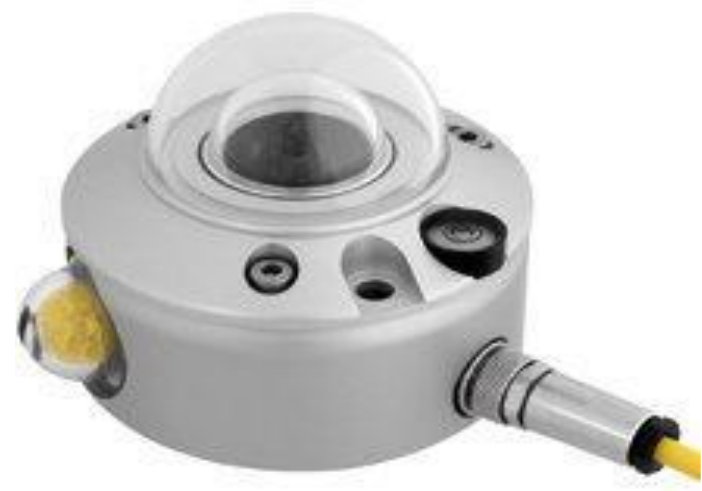

\section{Figure 1: The Pyranometer-2}

The primary data of daily solar radiation on horizontal surface for Jumla were collected from the archives of the Department of Hydrology and Meteorology, the Government of Nepal. Daily sunshine duration, temperature and rainfall data for these sites were obtained from the same Department. The data obtained covered years from 2015 years for Jumla. The most widely used ORIGIN/Microsoft Office Excel software have been used for data analysis.

CMP6 Pyranometer is shown in Figure 1. The CMP6 Pyranometer has an operating temperature is from $-40^{\circ} \mathrm{C}$ to $80^{\circ} \mathrm{C}$. It has wide spectral range of instrument from $310 \mathrm{~nm}$ to $2800 \mathrm{~nm}$. The sensitivity of instrument and field of view are 5 to $15 \mu \mathrm{V} / \mathrm{W} / \mathrm{m}^{\wedge} 2$ and $180^{\circ}$ respectively. In this instrument, the measuring data is recorded by LOGBOX SD data logger within a minute resolution for 24 hours. Its special features are low noise, high resolution and low power consumption. It works in all weather conditions. It collects the data at real time for the needs of meteorology and slow signal analysis. We can insert the SD memory card for long term data storage. For the communication, LOGBOX uses either RS232 or RS485 communication port (Keep and Zonen, 2008). 


\section{RESULT AND DISCUSSION}

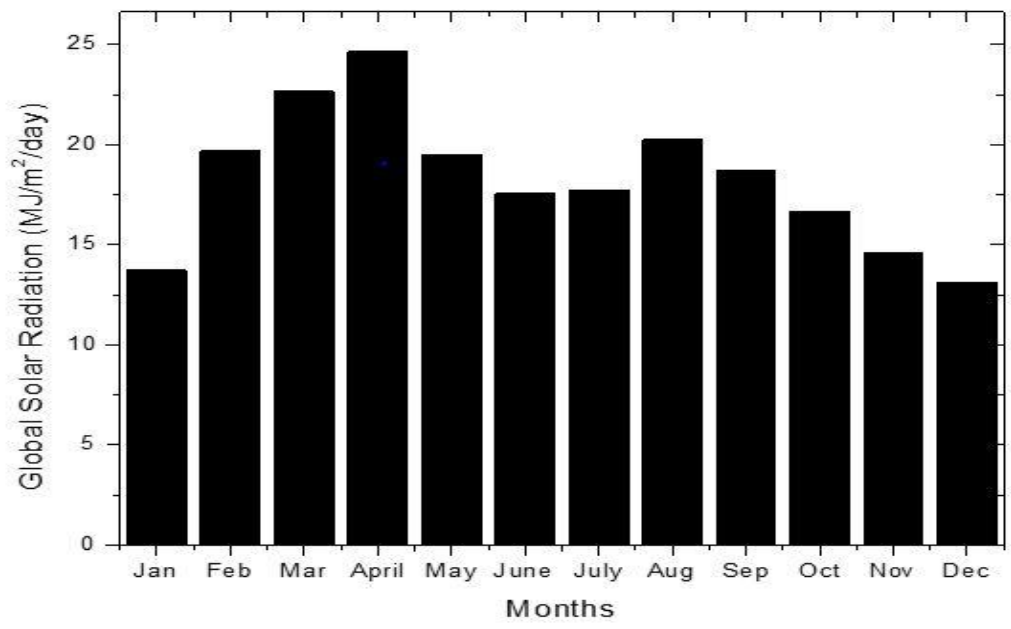

Figure 2: Monthly variation of Global Solar Radiation

Figure 2 shows the trend of measured and extraterrestrial global solar radiation is very much similar. However, there was maximum solar radiation $24.66 \mathrm{MJ} / \mathrm{m}^{2} /$ day is found in April. Hence statistical analysis indicates that the measured data are relevant as well as sufficient to explore the solar energy even in December when GSR is $13.10 \mathrm{MJ} / \mathrm{m}^{2} /$ day.

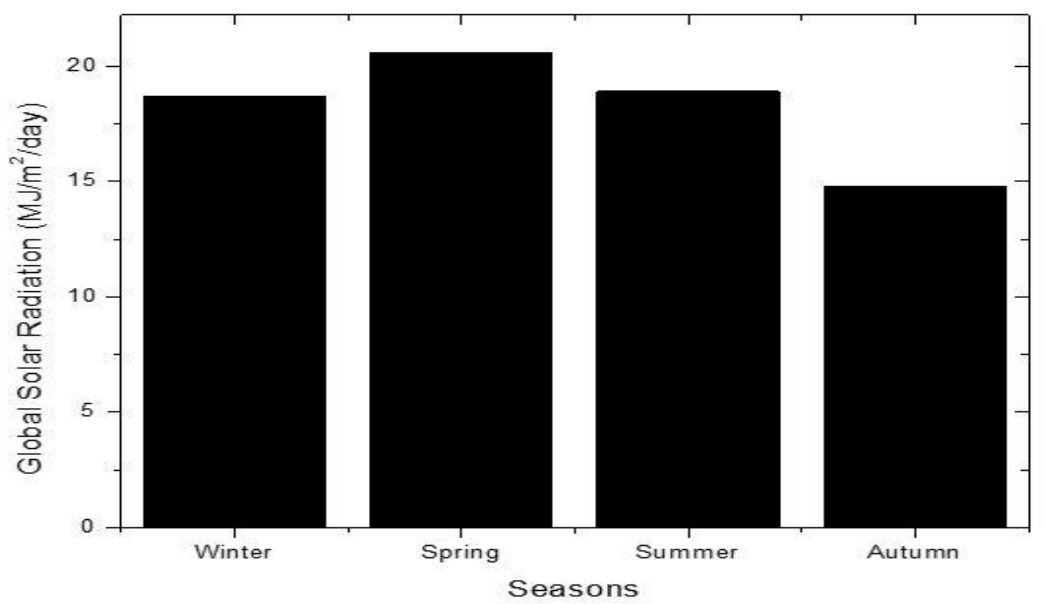

Figure 3: Seasonal variation of Global Solar Radiation

Figure 3 shows that the global solar radiation significantly fluctuates from season to season. The Jumla is part of the Himalayan region of Nepal. The measured solar energy for winter, spring, summer and autumn are $18.68,20.57,18.91$ and $14.79 \mathrm{MJ} / \mathrm{m}^{2} /$ day respectively. The maximum clear sky days are found in spring and minimum in Autumn. 
ISSN: 2362-1303 (Paper) | eISSN: 2362-1311 (Online)

JOURNAL OF ADVANCED ACADEMIC RESEARCH (JAAR)

June 2020

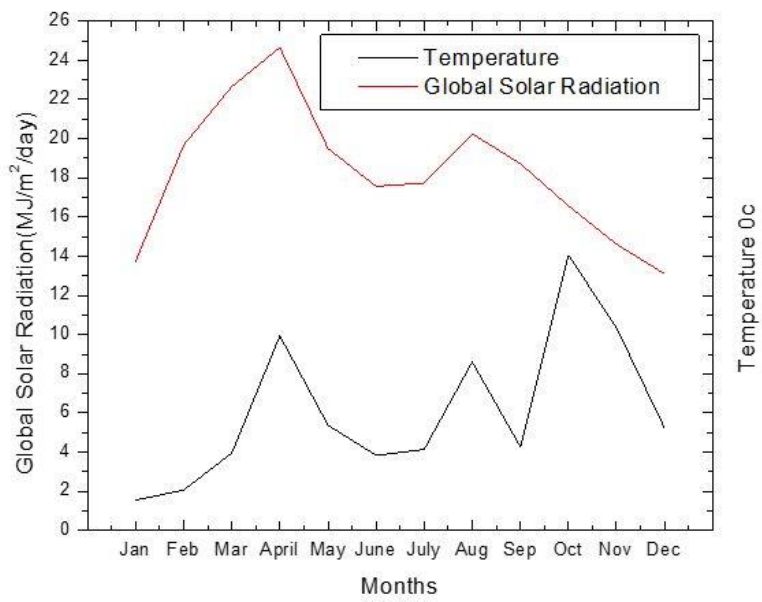

Figure 4: Variation of Global Solar Radiation with Temperature in 2015

It is observed that the global solar radiation varies with temperature throughout the year except in the summer which sees significant rainfall in the Jumla region as shown in the figure. The deviation of solar radiation from temperature in summer is primarily caused by the presence of cloud and precipitation (Figure 4).

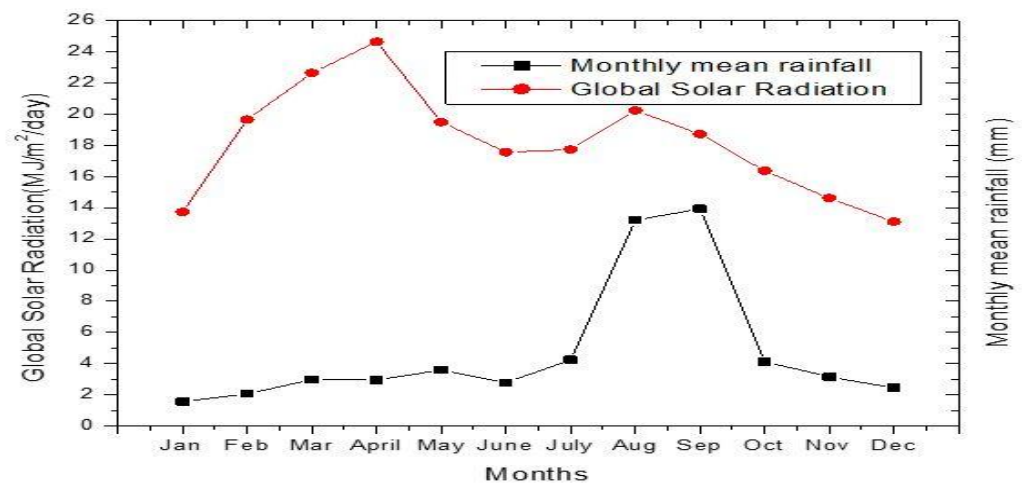

Figure 5: Monthly variation of Global solar radiation with rainfall in Jumla, 2015

From Figure 5 it is observed that Global solar radiation varies with rainfall. Maximum rainfall is observed in September so Global solar radiation is decreased. The cause of deviation of solar radiation is due to precipitation and cloud. 
ISSN: 2362-1303 (Paper) | eISSN: 2362-1311 (Online)

JOURNAL OF ADVANCED ACADEMIC RESEARCH (JAAR)

June 2020

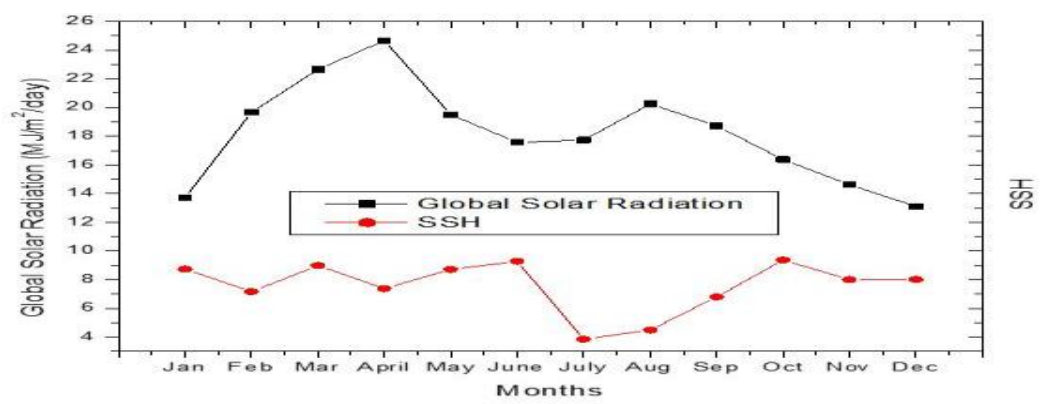

Figure 6:.Monthly variation of Global solar radiation with SSH (Sun Shine hour) in Jumla, 2015

From Figure 6 it is observed that Global solar radiation varies with SSH. Due to rotation of the earth, sunshine duration varies from season to season. Maximum SSH is observed in October. The cause of deviation of solar radiation is due to precipitation, cloud, rain and humid air. From figure it is noted that the lowest monthly average daily global solar radiation and monthly average sunshine duration in July are $17.73 \mathrm{MJ} / \mathrm{m}^{2} /$ day and 3.85 hours respectively.

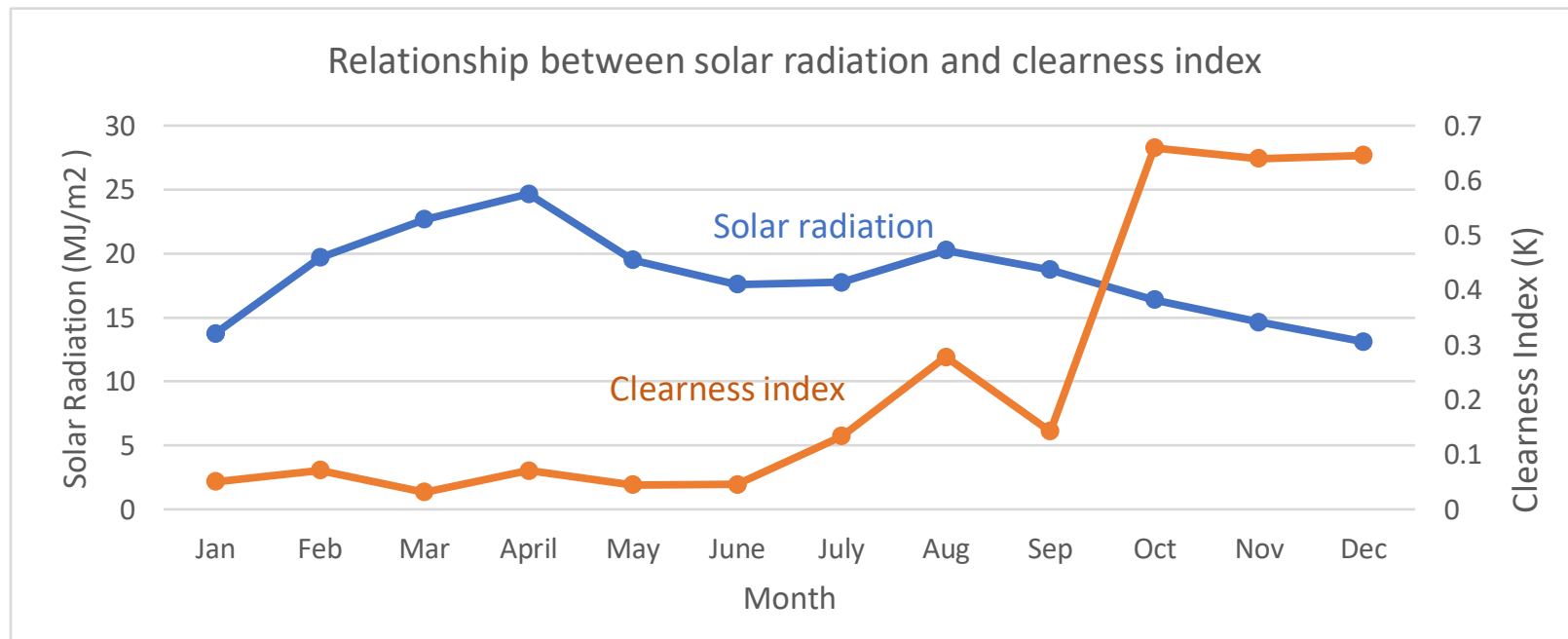

Figure 7: Seasonal variation of Global Solar Radiation with clearness index at Jumla for the year2015

The relationship between Global Solar Radiation and Clearness Index is shown in Figure 7. The given figure indicates that there is maximum amount of solar energy can be harvested in spring season. The clearness index is the ratio of measured global solar radiation $\left(\mathrm{H}_{\mathrm{g}}\right)$ to the extraterrestrial solar radiation $\left(\mathrm{H}_{\mathrm{o}}\right)$. It is concluded that there is sufficient energy even in the winter season. 
ISSN: 2362-1303 (Paper) | eISSN: 2362-1311 (Online)

JOURNAL OF ADVANCED ACADEMIC RESEARCH (JAAR)

June 2020

\section{CONCLUSIONS}

It is found that the annual average GSR $18.36 \mathrm{MJ} / \mathrm{m}^{2} /$ day in Jumla, the report showed that such amount of energy is sufficient to promote grid connected solar photovoltaic (PV) for power generating plants in Jumla. The global solar radiation varies from month to month and season to season depending on temperature and precipitation. The maximum and the minimum global solar radiation20.58 MJ/m² and14.79 $\mathrm{MJ} / \mathrm{m}^{2}$ are found in Spring and Autumn season in Jumla. However, low global solar radiation is measured in summer due to the cloud and rainfall at Jumla. Hence the topography, as well as local weather condition also plays a vital role in the estimation of global solar radiation in any part of the world including Nepal. This study recommends that Jumla and places having similar altitude/geographical/meteorological parameters are suitable for solar farming activities in Nepal.

\section{ACKNOWLEDGEMENTS}

The authors sincerely express deep thanks to the Department of Hydrology and Meteorology (DHM), Government of Nepal for providing relevant data. The support provided by Prof. Dr. Khem Narayan Poudyal, Prof. Dr. Indra Bahadur Karki and the staffs of the Department of Physics Mahendra Multiple Campus Nepalgunj is highly acknowledged.

\section{REFERENCES}

Adhikari, K.R. (2013). Estimation of Global Solar Radiation for Four Selected Sites in Nepal Using Sunshine Hours, Temperature and Relative Humidity. Journal of Power and Energy engineering, 1, 1-9, http://dx.doi.org/10.4236/jpee.2013.13003

Energy Efficiency and Conservation Agency (2001). Solar Energy Use And Potential in New Zealand. Wellington: Energy Efficiency and conservation agency.

KC, B.R. (2019). Estimation of Solar Energy Potential and its Utilization in Mid-Western region of Nepal, Doctoral Thesis, Mewar University, India (2019).

KC, B.R., and Gurung, S. (2015). A Journal of the Autar Dei Chaudharain Research Centre (ADCRC), 9,1-7.

Keep and Zonen (2008), Manual.

Nisha, S. G. (2016). Estimation of the Solar Energy Generation Potential on the Rooftop of the PTU college Campus. International Journal of Advanced

Research in Electrical Engineering, 5(5).

Nepal Energy Situation, (2013,). https://energypedia.info/wiki/Nepal_Energy_Situation.

Nisha, S. G. (2016). Estimation of the Solar Energy Generation Potential on the Rooftop of the PTU college Campus. International Journal of Advanced

Research in Electrical Engineering, 5(5).

Okonkwo, G. A.(2014). Estimating Global Solar Radiation. European Scientific Journal,10, $1857-7881$. 
ISSN: 2362-1303 (Paper) | eISSN: 2362-1311 (Online)

JOURNAL OF ADVANCED ACADEMIC RESEARCH (JAAR)

June 2020

Tsering, L. (1991). Role of Solar and wind energy in Nepal. Kathmandu:

Integral Centre for Integrated Mountain Development.

UNFCO (2012). District Profile Jumla.: United Nations Field Coordination, M.W.R.

WECS, Water and Energy Commission Secretariat (2010). Energy Synopsis Report, Government of Nepal. 